It is important that the donor be aware of the full extent of the powers that are being transferred to the donee. Although the powers will be monitored by the new Court of Protection and the Public Guardian, the anticipated risks are the potential for conflicts between the best interests of the donor and the interests of the donee who has the LPA.

\section{Research on vulnerable subjects}

The Mental Capacity Act 2005 regularises research on people lacking mental capacity. This is an important subject. Research involving human subjects is potentially important for society as a whole because of the possibility of advancement of knowledge. Strictly speaking, research on human subjects is only justifiable if there is a reasonable prospect that the study will generate the knowledge that is sought, that there is a need to use human subjects and that the selection of subjects is fair. It is also important that the benefits to the individual and to society outweigh the risk to the individual. Research on human subjects who lack mental capacity is potentially morally perilous because of the temptation to use the subjects simply as means to the ends of society as a whole. One of the cornerstones of the conceptualisation of autonomy in the tradition of Kant is that all persons must be treated as ends in themselves, that is as human subjects with dignity and value and not merely as means or objects. ${ }^{7}$

The Willowbrook case exemplifies the risks. The Willowbrook State School was an institution for mentally disabled children in New York. A number of these children, with the consent of their parents, were exposed to strains of an infectious hepatitis virus in order to study the period of infectivity. The aim was not immunisation. The justification was that they were likely to be infected in any case because viral hepatitis was endemic in the institution. One of the criticisms of this study was that the children were unlikely to benefit directly from the study and that the investigation was not aimed at furthering knowledge about the children's current medical conditions. In the light of the potential moral risks of using persons who lack mental capacity in research, the provisions of the Mental Capacity Act adequately balances these risks against the potential benefits.

The Act will come into effect in 2007. In the intervening period it is imperative that doctors and other agencies become fully aware of the provisions within the Act and also that training be widely available on the implications of the Act for clinical practice. Psychiatrists have been the resource in many hospital settings for the assessment of capacity in patients refusing treatment. There is no doubt that in the new dispensation, doctors of all specialties will have to become confident about their assessments of mental capacity. Clinical judgements on capacity as well as the physical status of patients must become uniformly routine judgements in all areas of medicine.

\section{References}

1 Beauchamp TL, Childress JF. Principles of biomedical ethics, 4th edn. Oxford: Oxford University Press, 1994.

2 The United Kingdom Parliament. www.publications.parliament.uk
3 Shickle, D. The Mental Capacity Act 2005. Clin Med 2006;6:169-73.

4 Christian Medical Fellowship. www.cmf.org.uk/index/mental_capacity_ act.htm

5 Zigmond, AS. Reform of Mental Health Act 1983: the Green Paper. Psychiatr Bull R Coll Psychiatr 2001;25:126-8.

6 Department of Health. Report of the expert committee: review of the Mental Health Act 1983. London: DH, 1999.

7 Kant I. Groundwork for the metaphysics of morals (translation and analysis, HJ Paton). London: Routledge, 1948.

\title{
Erratum
}

\section{Kingham JGC. Liver disease in pregnancy. Clin Med 2006;6:34-40}

Please note that in the above paper, p. 34, col 2, the order of the bulleted points was incorrect.

The pregnancy-specific conditions reported in a recent prospective study from South Wales should have been listed in the following order of frequency:

- liver dysfunction related to pre-eclampsia

- haemolysis, elevated liver enzymes, and low platelet count (HELLP syndrome)

- obstetric cholestasis (OC)

- hyperemesis gravidarum

- acute fatty liver of pregnancy. 